\title{
Sex Differences in Immunologic Reponse: Studies of Antibody Production by Individual Spleen Gells after Stimulus with Escherichia coli Antigen
}

\author{
J. F. KenNY ${ }^{[45]}$ AND J. A. GRAY \\ Department of Pediatrics, University of Pittsburgh School of Medicine, and the Children's Hospital of Pittsburgh, \\ Pittsburgh, Pennsylvania, USA
}

\section{Extract}

Specific antibody production by spleen cells of male and female mice during a noninvasive enteric infection with Escherichia coli and after parenteral injection of heatkilled $E$. coli was studied by use of the Jerne-Nordin agar plaque technique. Following experimental enteric colonization with $E$. coli 0127 significantly greater proportions of spleen cells produced specific anti-0 antibody in immature weanling female mice than in their male littermates. Anti-E. coli 0127 plaque-forming cells were also found in significantly greater numbers in the spleens of immature females than in males following intraperitoneal injection of small numbers of heat-killed E. coli. Although many spleens from male mice produced no cell plaques after a small dose of antigen, responses by the sexes were comparable after injection of large numbers of heatkilled bacteria.

Production of plaques by spleen cells from female animals after injection of small amounts of antigen increased significantly with age, but the responses observed in adult male mice were only slightly and insignificantly greater than those of male weanlings. Studies of the sizes of plaques produced by spleen cells of male and female animals showed no statistical differences. Young ovariectomized females responded in the same way as their sham-operated male littermates to small amounts of $E$. coli antigen. Administration of small doses of estrogen increased plaque formation by spleen cells of weanling males.

It appears that an effect of female sex hormones is production of greater numbers of antibody-producing cells; yet in the final phase of antibody production, individual cells from each sex produce on the average the same amounts of antibody.

\section{Speculation}

The better ability of the immature female to respond immunologically to a small amount of $E$. coli 0 antigen' may be a significant factor in her superior resistance to invasive disease with $E$. coli. Differences in the immune response of the two sexes appear to occur in the proliferative phase of antibody-producing process or steps leading up to this phase, but not in the final phases of antibody production by the cell. By mechanisms not yet defined, estrogen appears to enhance the proliferation of immunocompetent cells, and secretion of estrogen by the female may explain her superior immunologic responsiveness. 


\section{Introduction}

Little or no antibody against gram-negative enteric bacteria crosses the human placenta [12, 22]. Enteric bacteria which colonize the infant soon after birth are significant causes of severe infection and death during early life. For reasons presently unknown, male infants are particularly susceptible to systemic infections with gram-negative organisms during the first 2 months of life [15, 30]. Meningitis and sepsis are three times more frequent in male than in female infants, and death due to these infections is also more common in infant boys [37]. Recent data indicate that the newborn infant responds immunologically during the first few days of life to antigens derived from bacteria in his enteric tract [12]. The question is raised whether the immature male responds less well than the female to these antigens during these initial stages of antibody production and is thus more susceptible to invasive disease.

In the studies reported in this paper the Jerne-Nordin technique [13] has been used to study antibody production by spleen cells of immature male and female mice. Data show that following experimental enteric colonization with $E$. coli or after parenteral injection of small doses of $E$. coli 0 antigen significantly larger numbers of cells from immature females than from males produce specific antibody. Differences between male and female responses were most demonstrable when small doses of antigen were injected and became less distinct and statistically insignificant when larger doses were administered. Comparative studies of sizes of plaques produced by spleen suspensions of male and female animals showed no significant differences, suggesting that the better response of the female was probably attributable to production of antibody by more cells rather than to the production of more antibody per cell. Preliminary studies of the responses of gonadectomized females and males treated with estradiol suggested that estrogen influenced immunologic responsiveness and could be responsible for the sex differences observed.

\section{Methods and Materials}

\section{Test Organism}

A streptomycin-resistant strain of $E$. coli 0127: K63 (B8): NM was used to establish enteric colonization and prepare $E$. coli 0 antigen for injection. Characteristics of this strain of $E$. coli have been previously reported [16]. Although isolated from a human diar- rheal stool, this organism causes no disease in the mouse and following oral infections in weanling or adult animals bacterial growth remains confined to the lumen of the enteric tract [16]. An 18-hr broth growth stabilized with $15 \%$ glycerol was frozen at $-50^{\circ}$ in $0.5-\mathrm{ml}$ aliquots, one of which was used to prepare subcultures for each experiment. The numbers of bacteria in suspensions were adjusted by nephelometry with a spectrophotometer [16].

\section{Experimental Animals}

For most experiments litters of randomly bred Swiss Webster mice were adjusted at the time of weaning (3 weeks of age) to contain equal numbers of males and females. With the exception of those studies specifcally described below all experiments were performed with equal numbers of male and female weanling littermates that were 3-3.5 weeks old and weighed between 12 and $15 \mathrm{~g}$. In one experiment in which the effects of aging on response were studied, 120 animals were acquired at 3 weeks of age; half were studied at this time and half when they were 9 weeks old, at a time when they weighed between 30 and $35 \mathrm{~g}$. In one group of experiments in which the effects of ovariectomy on immune response were studied, 11 litters with 90 weanlings were adjusted to contain approximately 2 females to 1 male. Equal numbers of female littermates were ovariectomized or sham-operated and the males were sham-operated. Ovariectomies and sham operations were performed through bilateral flank incisions under ether anesthesia when animals were 3-4 weeks old. Immune responses of the three operated groups were then compared when the animals were 6 weeks old.

Fifteen litters consisting of 103 male weanlings were used for experiments in which the effect of treatment with estradiol on plaque formation was studied. Half of each litter was designated as part of the treatment group, the other half as controls. On day 6 and day 3 prior to death animals in the treatment groups received by intramuscular injection $250 \mathrm{ng}$ estradiol $17 \beta$ suspended in $0.1 \mathrm{ml}$ saline [41]; controls received saline alone.

Previous studies in this laboratory showed that natural antibody to $E$. coli was usually not passively transferred in significant amounts to the infant mouse and these antibodies were not detected in the serum of most mice until after 3 weeks of age. Significant quantities of $E$. coli antibody were not produced in response to stimulus from the enteric tract until after this time [16]. 


\section{Enteric Infection}

Enteric infection with $E$. coli 0127 was established following oral pretreatment with streptomycin and other antibiotics as in previous studies [16]. The infecting dose consisted of $10^{8} E$. coli in $0.1 \mathrm{ml}$ sterile saline which was administered by stomach tube. To insure that colonization had been established and was persistent, stool cultures were obtained 2 days after oral feeding of bacteria and then again on the day before killing. Organisms in the stool were identified by agglutination with specific $\mathrm{OB}$ antiserum. For reasons to be discussed, mice were killed 8 days after oral infection.

\section{Parenteral Immunization}

Escherichia coli 0127 antigen was prepared by heating a 6 -hr broth culture at $100^{\circ}$ for $1.5 \mathrm{hr}$. Heat-killed bacteria were washed three times in saline and adjusted to a suspension containing $10^{9}$ bacteria $/ \mathrm{ml}$ and stored at $4^{\circ}$. As required, 10-fold dilutions of this suspension were prepared in sterile saline for injection. Antigen was injected intraperitoneally in $0.3-$ to $0.5-\mathrm{ml}$ amounts. Spleens were removed 4 days after injection, the time expected for maximum plaque counts [14].

\section{Immune Response}

Following oral infection and parenteral injection of 0 antigen the numbers of antibody-producing cells in the spleen were determined by the counts of hemolytic plaques according to the technique of Jerne and Nordin [13]. The direct technique which permits enumeration of cells producing IgM antibody of high hemolytic efficiency was used; only primary responses were studied. The technique was adapted for detection of cells producing antibody to $E$. coli antigen [21]. Sheep erythrocytes that had been stored $1-3$ weeks in Alsevers solution were washed three times and modified with soluble heat-extracted 0127 antigen [23] and then washed three times with saline before use. Spleen cells were suspended in $5 \mathrm{ml}$ Eagles medium and plated in 0.1-ml amounts. Plates containing both $E$. coli-modified and -unmodified cells were prepared simultaneously in duplicate, and total cells producing antibody to $E$. coli were corrected for those producing natural antibody to sheep erythrocytes. Guinea pig serum, used as complement, was either freshly frozen or lyophilyzed; it was diluted with saline to contain 20-25 units $/ \mathrm{ml}$ as determined by the method of Mayer [19] and applied to plates in 2-ml amounts. Plaques on each plate were counted without knowledge of the sex or experimental group of the animal. Count- ing was facilitated by application of a benzadine stain [14]. Following dilution of spleen cell suspensions $1 / 100$ in $0.1 \mathrm{~N} \mathrm{HCl}$, total mononuclear cells for each spleen were estimated by counting nucleated cells in a Neubauer chamber. Sizes of plaques were measured under $20 \times$ magnification with an eyepiece micrometer accurate to $0.001 \mathrm{~mm}$. Two diameters for each plaque were measured and averaged.

\section{Statistical Analysis}

Total plaque counts for individual male and female animals or for control and experimental groups were ranked according to total plaques per spleen and per $10^{8}$ spleen cells. Data were analyzed by median and $\mathrm{H}$ tests [6]. Counts of total cells per spleen for males and females were analyzed by median tests, and, in addition, mean counts of mononuclear cells per spleen were compared by Student's $t$ test. Plaque sizes were compared by Student's $t$ test.

\section{Results}

\section{Enteric Infections}

Plaque counts per spleen obtained in a preliminary experiment for which 4-15 animals a day were killed at intervals following experimental colonization with E. coli 0127 are shown in Table I. Small numbers of background hemolytic plaques specific for $E$. coli 0127 were found in animals prior to infection. Data from larger numbers of normal animals of different ages showed that a few background plaques were usually produced by the spleens of most animals older than 3 weeks of age that have not had any known exposure to this bacteria. After oral infection, anti-E. coli plaqueforming cells continued to increase in number for 12 days, although most animals on day 12 had plaque counts similar to those on day 8 , indicating a probable leveling off of response during week 2 of infection. After week 1, colonization with $E$. coli 0127 became irregular as increasing numbers of animals acquired other coliforms in their stool. For this reason the 8th day following oral infection was chosen for studies of larger numbers of male and female animals. It appeared to be the optimal time for studies because significant immune responses had occurred at this point and because coliform flora in the stool was still almost exclusively $E$. coli 0127 .

In three experiments 49 male and 50 female weanlings were killed 8 days after oral infection. Distribution of total plaques per spleen and per $10^{8}$ spleen cells for males and females are shown in Figures 1 and 
Table I. Anti-E. coli 0127 plaques produced by spleen suspensions from weanling mice at intervals following enteric infection with E. coli 0127

\begin{tabular}{llllll}
\hline & \multicolumn{4}{c}{ Plaques/spleen } \\
\cline { 2 - 6 } & Preinfection & Day 5 & Day 8 & Day 12 \\
\hline Male & $0.70(2)^{2}$ & $1.66 \pm 0.54(6)$ & $2.00 \pm 0.37(7)$ & $2.29 \pm 0.23(4)$ \\
Female & $1.55(2)$ & $1.93 \pm 0.40(6)$ & $2.91 \pm 0.15(8)$ & $2.95 \pm 0.46(4)$ \\
\hline
\end{tabular}

1 Expressed as $\log _{10}$ of the geometric mean \pm 1 SEM.

${ }^{2}$ Number in parentheses indicates number of animals.

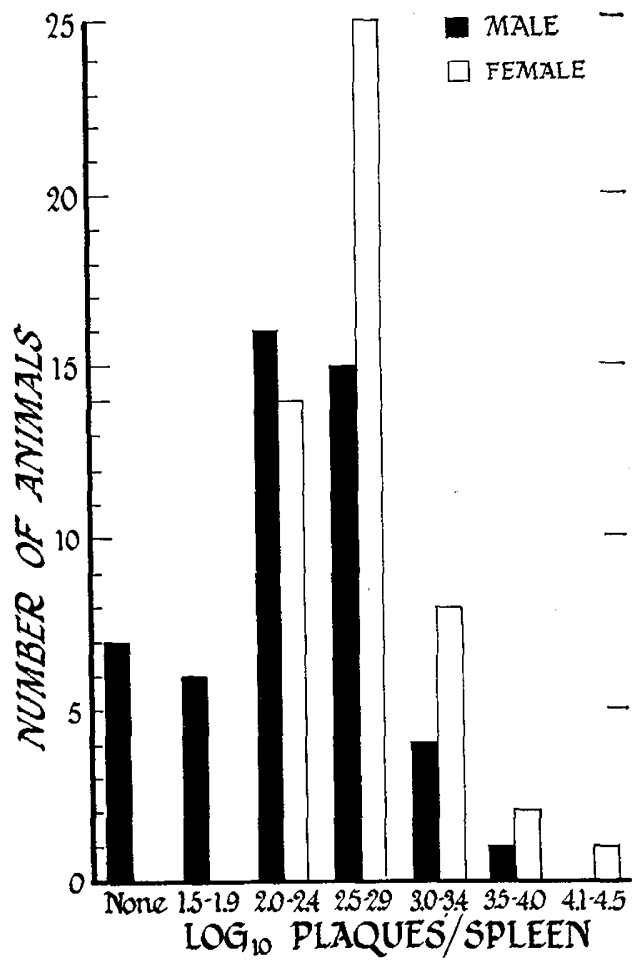

Fig. 1. Frequency distribution of total anti-E. coli 0127 plaques produced by spleen suspensions of male and female weanling mice 8 days after oral infection with E. coli 0127.

2. Spleen suspensions from 7 of 49 males (14\%) produced no plaques and 6 males (12\%) had fewer than $100 /$ spleen. None of the spleen suspensions from females produced less than 100 plaques. Frequency distribution of plaque counts per $10^{8}$ spleen cells was similar to that for plaques per total spleen, indicating that not only were more cells producing antibody in the female but also greater proportions of total spleen cells were producing antibody. Ranges and medians of plaque counts for all animals and each sex individually for this and other experiments are summarized in Table II. It was noted that twice as many females as males had plaque counts above the population median.

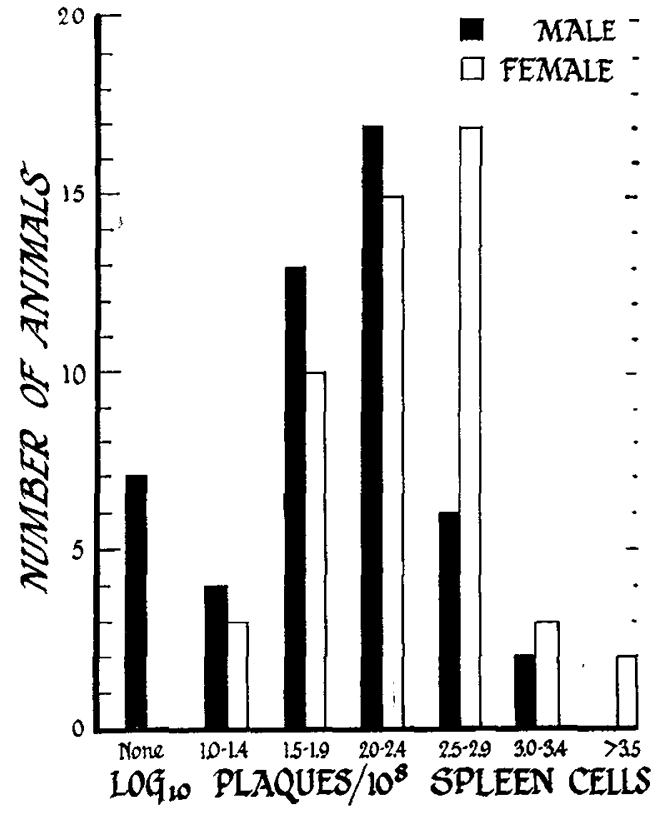

Fig. 2. Frequency distribution of anti-E coli 0127 plaques per $10^{8}$ spleen cells produced by spleen suspensions of male and female weanling mice 8 days after oral infection with E. coli 0127 .

\section{Response to Parenteral Antigen}

Results of responses of male and female weanlings studied 4 days after the injection of $3 \times 10^{5}$ and $3 \times$ $10^{8}$ heat-killed $E$. coli are shown in Figures 3 and 4 . Each figure represents the results obtained from 80 mice during two experiments for each of which 20 males and 20 females were killed. Following the smaller dose of antigen females responded significantly better than males. As noted in Table II, similar to the findings with enteric colonization, twice as many females as males had plaque counts above the population median. After the large dose of antigen, male and female responses were comparable. Males still predominated among animals with very low counts (six males and two females had fewer than $100 /$ spleen) and one female had an extremely good response (31,725 plaques/spleen). Following the large dose of antigen, 
Table II. Anti-E. coli 0127 plaques produced by spleen suspensions from weanling mice in three groups of experiments

\begin{tabular}{|c|c|c|c|c|c|c|c|c|c|c|}
\hline \multirow{2}{*}{ Exp. } & \multirow{2}{*}{$\begin{array}{c}\text { No. } \\
\text { of } \\
\text { animals }\end{array}$} & \multirow{2}{*}{ Range } & \multirow{2}{*}{$\begin{array}{c}\text { Popula- } \\
\text { tion } \\
\text { median }\end{array}$} & \multicolumn{2}{|c|}{$\begin{array}{c}\text { Counts above } \\
\text { median, } \\
\% \text { total } \\
\end{array}$} & \multirow{2}{*}{$\begin{array}{c}\text { Range } \\
\text { of males }\end{array}$} & \multirow{2}{*}{$\begin{array}{c}\text { Male } \\
\text { median }\end{array}$} & \multirow{2}{*}{$\begin{array}{l}\text { Range of } \\
\text { females }\end{array}$} & \multirow{2}{*}{$\begin{array}{l}\text { Female } \\
\text { median }\end{array}$} & \multirow{2}{*}{$\begin{array}{c}\text { Comparison } \\
\text { male-female } \\
\text { responses }\end{array}$} \\
\hline & & & & Males & $\begin{array}{l}\mathrm{Fe}- \\
\text { males }\end{array}$ & & & & & \\
\hline \multicolumn{11}{|l|}{0127 Enteric infection } \\
\hline plaques/total spleen & 99 & $0-14,200^{1}$ & 425 & 29 & 71 & $0-4550$ & 225 & $100-14,200$ & 575 & $P<0.001$ \\
\hline plaques $/ 10^{8}$ spleen cells & & $0-4190$ & 206 & 35 & 65 & $0-1390$ & 108 & $22-4190$ & 272 & $P<0.001$ \\
\hline \multicolumn{11}{|l|}{$3 \times 10^{5}$ heat-killed $E$. coli $^{2}$} \\
\hline plaques/total spleen & 80 & $0-1125$ & 75 & 28 & 72 & $0-1125$ & 25 & $0-975$ & 125 & $P<0.001$ \\
\hline plaques $/ 10^{8}$ spleen cells & & $0-780$ & 51 & 33 & 67 & $0-625$ & 15 & $0-780$ & 91 & $P<0.001$ \\
\hline \multicolumn{11}{|l|}{$3 \times 10^{8}$ heat-killed $E$. coli ${ }^{2}$} \\
\hline plaques/total spleen & 80 & $0-31,725$ & 950 & 52 & 48 & $0-10,675$ & 975 & $0-31,725$ & 825 & NS \\
\hline plaques $/ 10^{8}$ spleen cells & & $0-25,200$ & 476 & 51 & 49 & $0-9100$ & 476 & $0-25,200$ & 436 & NS \\
\hline
\end{tabular}

${ }_{1}^{1}$ Total anti-E. coli plaques were calculated following correction in each instance for naturally occurring anti-sheep cell plaques observed on control plates prepared with unmodified sheep erythrocytes. In every experiment background plaques for one fiftieth of the spleen averaged less than 2 plate. For the three groups of experiments mean background plaque counts for females were $1.3 \pm 0.2$ and for males $1.8 \pm 0.2$ per plate.

2 Intraperitoneal administration.

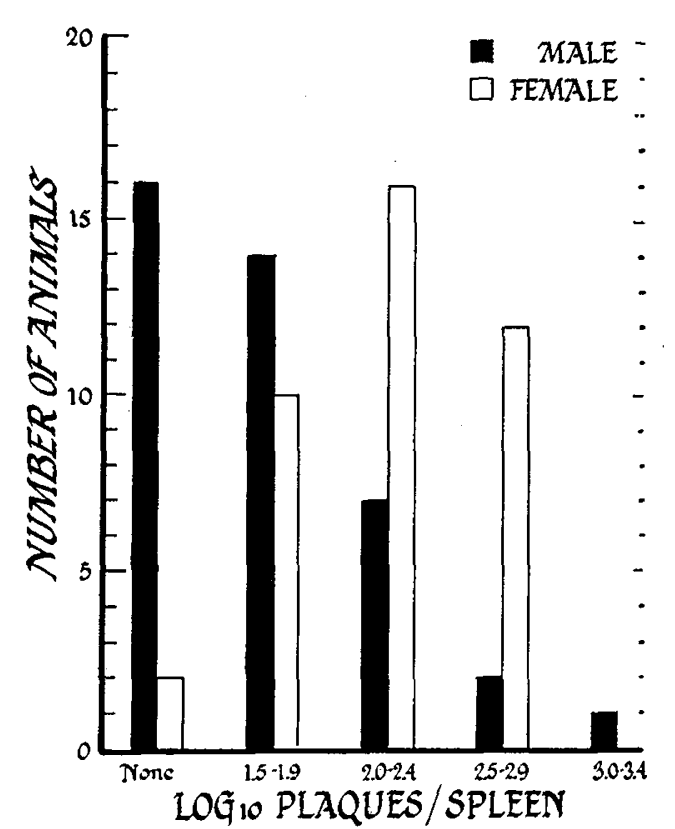

Fig. 3. Total anti-E. coli 0127 plaques per spleen in male and female weanling mice 4 days after intraperitoneal injection of $3 \times 10^{5}$ heat-killed $E$. coli 0127 .

however, the responses of the two sexes, when analyzed by median test, were not statistically different (Table II).

\section{Effect of Age}

The effect of aging on the ability to respond to a small dose of antigen is shown in Figure 5. Responses of mature adults of 9 weeks of age were compared with

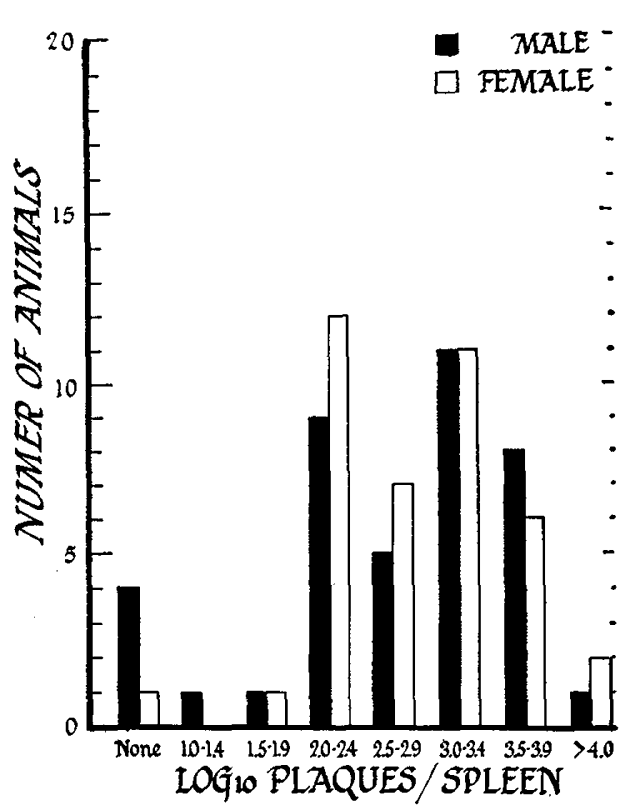

Fig. 4. Total anti-E. coli 0127 plaques per spleen in male and female weanling mice 4 days after intraperitoneal injection of $3 \times 10^{8}$ heat-killed $E$. coli 0127 .

those of 3-week-old weanlings, both of which were injected with $3 \times 10^{5}$ organisms from the same lot of antigen. This lot of antigen was different from that used for the preceding experiments. As judged by plaque counts, responses of males and females improved with age but those of the females remarkably more than those of the males. Large numbers of mature males, as well as immature males, failed to demonstrate any response whereas spleen suspensions from 
all adult females produced plaques. Statistical comparison of the responses of males at 3 and 9 weeks of age showed no significant difference whereas female responses at 3 and 9 weeks of age compared by median test were significantly different $(P<0.001)$.

\section{Plaque Size}

In one experiment 4 days following the injection of $3 \times 10^{6} \mathrm{E}$. coli intraperitoneally, total plaque counts for 22 weanlings (10 females and 12 males) were enumerated and then two diameters of all plaques situated on the central flat surface of the agar were measured. Results are shown in Table III. While there was considerable variation in sizes of individual plaques and mean plaque sizes for individual animals, this var-

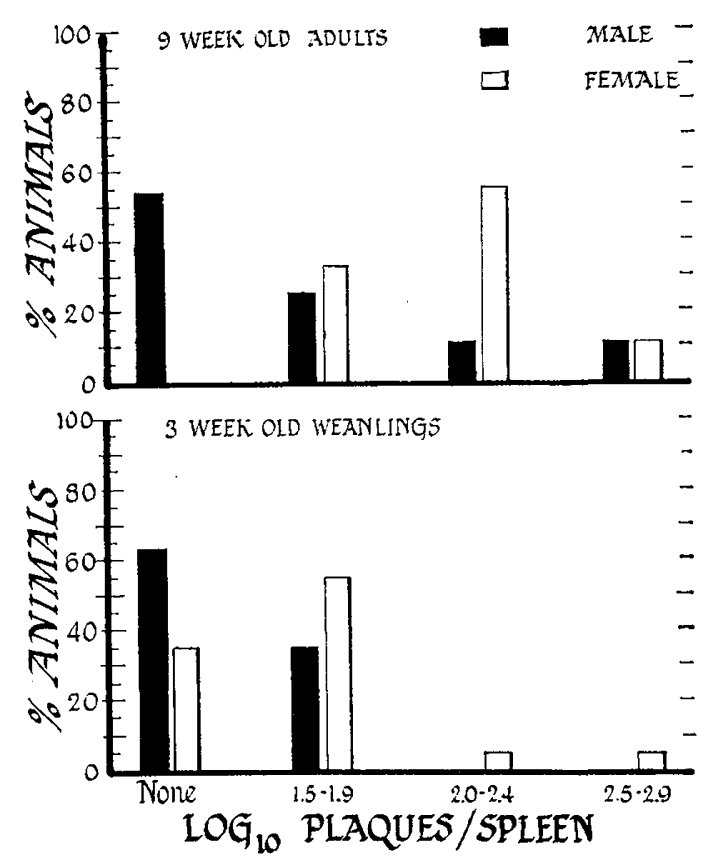

Fig. 5. Comparison of total anti-E. coli 0127 plaques produced by spleen suspensions of male and female weanling and adult mice 4 days after intraperitoneal injection of $3 \times 10^{5}$ heat-killed E. coli 0127 . iation was similar for males and females. Mean plaque size for 10 females with total plaque counts ranging from 75 to 6400 was $0.400 \pm 0.028 \mathrm{~mm}$; for 12 males with total plaque counts ranging from 50 to 1175 mean plaque size was $0.411 \pm 0.027 \mathrm{~mm}$. Mean plaque sizes for male and female animals were not statistically different, and for individual animals, there was no relation between mean plaque size and plaque count.

\section{Total Mononuclear Cells per Spleen}

Total mononuclear cells per spleen for males and females for each group of experiments in which normal weanling animals were studied are noted in Table IV. It has been reported that on a weight basis female mice have proportionately more lymphoid tissue for their body weight than males [28.] In these experiments, total counts of cells per spleen were not statistically different for males and females. Although values are not shown, older animals studied in other experiments had total spleen counts in the same range as the younger animals, and there were no significant differences between counts of mononuclear cells in 9-weekold and 3-week-old animals. There was no correlation between total plaque count and total mononuclear cells in the spleen in either males or females.

Table IV. Numbers of mononuclear cells per spleen for male and female weanling mice in three groups of experiments

\begin{tabular}{lcc}
\hline & $\begin{array}{c}\text { Range, } \\
\times 10^{8}\end{array}$ & $\begin{array}{c}\text { Mean } \times 1 \mathrm{1sE}, \\
\times 10^{8}\end{array}$ \\
\hline $\begin{array}{c}\text { Males } \\
\text { Injected with } 3 \times 10^{5} \text { heat- } \\
\text { killed } E \text {. coli }\end{array}$ & $0.31-4.33$ & $2.02 \pm 0.19$ \\
$\quad \begin{array}{l}\text { Injected with } 3 \times 10^{8} \text { heat- } \\
\text { killed } E \text {. coli }\end{array}$ & $0.58-7.13$ & $2.36 \pm 0.23$ \\
$\quad \begin{array}{l}\text { Orally infected with } E . \text { coli } \\
\text { Females } \\
\quad \text { Injected with } 3 \times 10^{5} \text { heat- } \\
\quad \text { killed } E . \text { coli }\end{array}$ & $0.74-4.67$ & $2.43 \pm 0.15$ \\
$\quad \begin{array}{l}\text { Injected with } 3 \times 10^{8} \text { heat- } \\
\quad \text { killed } E . \text { coli }\end{array}$ & $0.48-4.83$ & $1.78 \pm 0.16$ \\
$\quad$ Orally infected with $E$. coli & $0.50-4.50$ & $2.50 \pm 0.15$ \\
\hline
\end{tabular}

Table III. Plaque size ${ }^{1}$ in one experiment for which animals received $3 \times 10^{6}$ heat-killed E. coli 0127

\begin{tabular}{|c|c|c|c|c|}
\hline & \multicolumn{3}{|c|}{ Range } & \multirow{2}{*}{$\begin{array}{l}\text { Mean size } \\
\text { for all animals }\end{array}$} \\
\hline & $\begin{array}{l}\text { Plaque counts/ } \\
\text { spleen }\end{array}$ & $\begin{array}{r}\text { Individual } \\
\text { plaque sizes }\end{array}$ & $\begin{array}{c}\text { Mean size for } \\
\text { individual animals }\end{array}$ & \\
\hline Females $(10)^{2}$ & $75-6400$ & $0.123-0.884$ & $0.288-0.559$ & $0.400 \pm 0.028^{3}$ \\
\hline Males $(12)^{2}$ & $50-1175$ & $0.188-0.875$ & $0.202-0.583$ & $0.411 \pm 0.027$ \\
\hline
\end{tabular}

\footnotetext{
1 In millimeters.

2 Numbers in parentheses indicate numbers of animals.

${ }^{3}$ Mean \pm 1 SEM.
} 
Effects of Ovariectomy and Treatment with Estradiol $17 \beta$

Female mice that had been ovariectomized at 3-4 weeks of age and their male and female littermates that had been sham-operated at the same time received $3 \times 10^{5}$ heat-killed bacteria 1.5-2 weeks after operation and were killed 4 days later. Results are shown in Figure 6. Though responses of these animals were quantitatively less than those observed in the normal animals studied, it was apparent that sham-operated females responded considerably better than the ovariectomized females or sham-operated males. Responses of the ovariectomized females and sham-operated males were alike whereas the responses of the sham-operated females were significantly better when compared statistically with either of the other groups ( $P$ $<0.001$ )

Comparison of the responses of estrogen-treated weanling males and their control littermates are shown in Figure 7. Animals received $250 \mathrm{ng}$ estradiol 6 and 3 days prior to death and $5 \times 10^{5}$ heat-killed bacteria 4 days before death. Males treated with this relatively small dose of estrogen responded better than controls

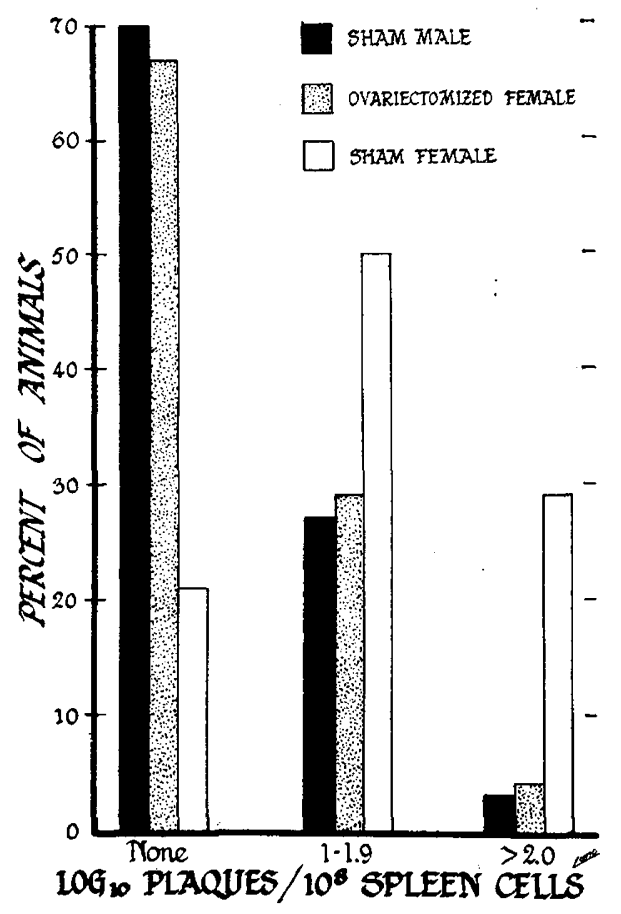

Fig. 6. Comparison of anti-E. coli 0127 plaques per $10^{8}$ spleen cells produced by spleen suspensions of ovariectomized females and their sham-operated female and male littermates. All animals received $3 \times 10^{5}$ heat-killed E. coli 0127 intraperitoneally 4 days previously.

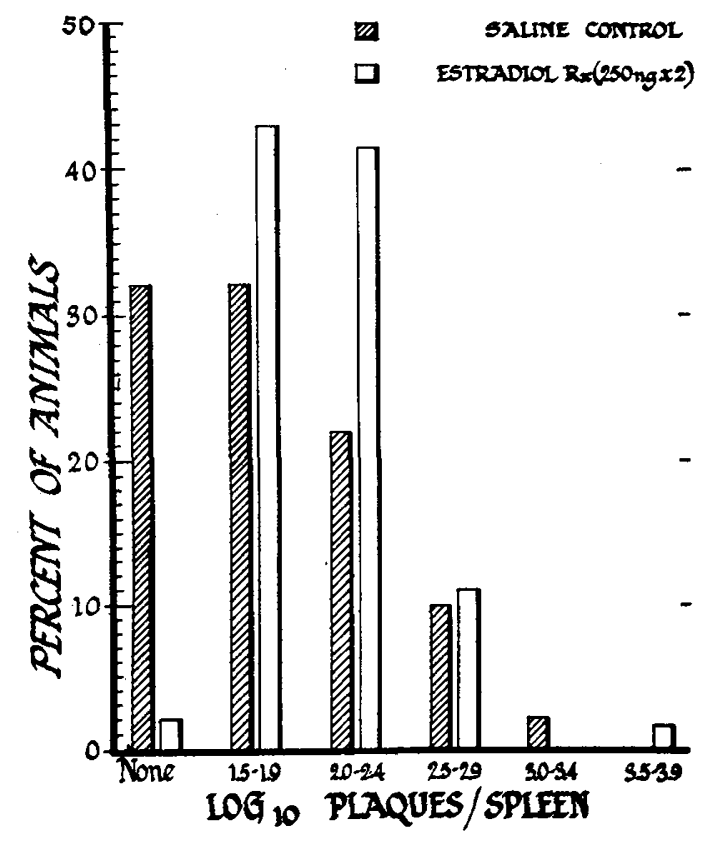

Fig. 7. Total anti-E. coli 0127 plaques produced by spleen suspensions of male weanlings pretreated with $500 \mathrm{ng}$ estradiol $17 \beta$ and saline-injected controls. Results were obtained 4 days after all animals received $5 \times 10^{5}$ heat-killed $E$. coli 0127 intraperitoneally.

$(P<0.05)$. Spleen cells of $98 \%$ of the estradiol-treated males produced anti-E. coli plaques in contrast to only $68 \%$ of the spleen cells from saline-injected controls $(P<0.001)$. Sham-operated and ovariectomized animals and estrogen-treated animals had mean total counts of mononuclear cells in the spleen similar to the normal animals studied.

\section{Discussion}

That human males are more susceptible to certain infections, including those with gram-negative bacteria in infancy, has been frequently noted, and this susceptibility has been extensively reviewed recently [37]. While the reasons for these sex differences in susceptibility to infection are unclear, data from recent studies indicate that females respond better immunologically. Kunin [18] studied naturally occurring bacterial hemagglutinins to 11 nonenteropathogenic serogroups of $E$. coli in the sera of over 200 human beings from 1 week to 37 years of age. Females tended to have higher titers, most notably in infancy and later childhood and adulthood. While mean titers of males and females in different age groups were not different statistically except in one instance (probably because of small numbers in each group) the trend for high titers among 
females was consistent for all the $E$. coli serogroups studied. Quantitative immunoglobulin studies have shown that in later childhood and adulthood females also tend to have higher IgM levels than males [7].

There is evidence that certain animals demonstrate similar sex differences in susceptibility to experimentally induced infections and in antibody production. Wheater and Hurst [39] showed a higher morbidity and mortality among male mice than female mice infected intraperitoneally with streptoccocci and other organisms. The better resistance of the female was evident when infections were modified by immunization or antibiotics; overwhelming infections tended to cause equal morbidity and mortality in both sexes. Other evidence shows that female mice also produce more specific antibody. Degradation of bovine serum albumin was more rapid when injected into females previously immunized with this protein than in males [32]. Titers of antibody to sheep red cells [31] and tumor cells [1] were higher in immunized females of certain strains of mice.

The results of the present studies are consistent with these previous findings and suggest that the better immune response of the female is the result of the function of larger numbers of antibody-producing cells. Plaque size may depend on a number of factors including availability of complement, number and age or lysability of the erythrocytes, as well as the kind and amount of antibody produced by the cell during the incubation period. However, in a single experiment where the same lots of reagents, complement, and erythrocytes have been used (thus minimizing the effects of these variables), and assuming in this primary response that all antibody is IgM, measurement of plaque size seemed a reasonable way of estimating whether there were significant differences in the amounts of antibody produced by individual male and female cells. Although there was much variation in plaque size for both sexes, mean plaque sizes were not different. Thus, data suggest that the proliferative phase of antibody production, i.e., that involving division of the antigen-sensitive lymphoid cells or the steps leading up to this phase, is different but that in the final phases of antibody production individual cells from each sex produce on the average the same amount of antibody.

That females respond better than males following small doses of antigen but that males are capable of significant responses following larger doses is of interest and suggests more efficient phagocytosis or processing of antigen by the female or that smaller amounts of antigen are required to stimulate proliferation of antigen-sensitive lymphocytes in the female. Why the sex differences become less distinct following large doses of antigen is as yet unexplained. Studies with increasing doses of sheep erythrocytes show that maximum cell-plaque responses are achieved with $4 \times 10^{7}$ cells; plaque counts tend to plateau or even decline with larger doses [17, 40]. Further investigations are necessary to determine what dose of $E$. coli 0127 saturates the response system and whether the saturating dose differs for the two sexes. There is some evidence that antigen-sensitive progenitors of antibody-producing cells may have varying degrees of affinity for antigen; those with high antigen affinity proliferate following small doses of antigen and those with less affinity proliferate with larger doses [25]. It is conceivable that females have more of those cells with high antigen affinity, thus showing better response with lower doses. Large doses of $E$. coli antigen or endotoxin suppress response [2] as does specific antibody [3]. Whether the suppressive effects of these agents differ for males and females is not yet known, although this information might be useful in interpreting the results obtained with the large dose of antigen. It is conceivable that the responses of some females had been suppressed at the higher dose. That the female does respond better to a small dose of antigen may be a significant factor in her better resistance to invasive disease. After enteric colonization, when initial growth of an organism remains confined to the lumen of the intestine, it is likely that relatively small amounts of 0 antigen are systemically absorbed $[8,27]$. Ability to produce antibody at this point might prevent parenteral invasion which could occur at a later time when the organism has become well established in the host.

The basis for the better immunologic responsiveness of the female is unknown. In the human being, the sex-linked patterns of inheritance of phagocytic lysosomal enzyme defects and certain immunodeficiency diseases suggest that genes on the $\mathrm{X}$-chromosome may play a role in bacterial killing and digestion (antigen processing) and in proliferation of immunocompetent cells. It has been theorized that the female, by virtue of possession of two $\mathrm{X}$ chromosomes, benefits from greater genetic heterozygosity [37]. While the immaturity of the animals used in most of these studies might first indicate a genetic reason for the observed sex differences, evidence from preliminary experiments suggests that in the mouse these differences are mediated by hormones. The better ability of the young female mouse to respond to small doses of $E$. coli antigen 
increases with maturity and is lost after removal of her ovaries. Young males respond better immunologically to small amounts of $E$. coli antigen if pretreated with small doses of estrogen. A number of previous studies have shown that treatment with estrogen results in enhanced reticuloendothelial function and host resistence. Nicol and associates [24] demonstrated in extensive studies that natural and synthetic estrogens stimulated phagocytosis in the mouse. Studies more recently reported have shown that estrogen acts by increasing the number of phagocytic cells which take up particles [9]. In other studies, administration of estrogen increased resistence to experimental infections in mice $[24,39]$ and raised the levels of gamma globulin or antibody in guinea pigs [24], mice [31], and rabbits [5, $35,36,38]$. It has also been observed that estrogen increased the mitotic index of lymphatic tissues [20].

Although sensitive and accurate methods have not been available for large scale study of estrogen secretion in immature subjects, indirect evidence suggests that the gonad of the child or immature animal is to some degree functional [11]. In studies of urethral cytology, a sensitive index of hormone balance in the human being, prepubertal boys and girls had evidence of difference in sex hormone secretion; females had greater proportions of superficial squamous cells with staining properties characteristic of "estrogen effect" [26]. By this technique, differences in estrogen effect have been noted even between prematurely born male and female infants from 1 to 12 weeks of age [29]. In some animals, it has been demonstrated that secretion of the fetal or immature gonad is necessary for the normal development of the male and female reproductive systems [11]. For example, vaginal opening, an estrogen-dependent process, may occur at 3-4 weeks of age in the mouse, although reproduction usually does not take place until after the second month of life [4]. While many studies show that estrogen stimulates reticuloendothelial activity and antibody production, there are other studies that show that it has a suppressive effect $[1,33,34]$, particularly on thymic-related lymphoid tissue [33] and still others that show no effect [10]. No doubt dosage of estrogen and timing in relation to the administration of antigen, the amounts and type of antigen, and type of estrogen, are important in the various effects observed. Further investigations are needed to define more precisely the effects of estrogen on various aspects of reticuloendothelial function and the mechanisms by which it enhances the proliferation of immunocompetent cells.

\section{Summary}

The direct Jerne-Nordin hemolysis-in-gel technique has been used to study the production of antibody to E. coli 0127 by single spleen cells in male and female mice. Following enteric colonization with $E$. coli or after the intraperitoneal injection of small numbers of heat-killed $E$. coli proportionately more cells produced antibody in immature weanling female mice than in male mice. Both sexes responded similarly to an intraperitoneal injection of a large number of heat-killed bacteria.

The ability of the weanling female mouse to respond better than the male to small amounts of $E$. coli antigen persisted and became even more evident in adulthood. Although spleens from female animals produced more anti- $E$. coli plaques, the mean size of these plaques was not different from that of the male animals. Ovariectomized female animals responded quantitatively to small amounts of $E$. coli antigen in the same manner as males, and small amounts of estradiol administered to male weanlings increased their immunologic responsiveness.

\section{References and Notes}

1. Batchelor, J. R., and Chapman, B. A.: The influence of sex upon the antibody response to an incompatible tumor. Immunology, 9: 553 (1965).

2. BRitton, S.: Regulation of antibody synthesis against Escherichia coli endotoxin. II. Specificity, dose requirements and duration of paralysis induced in adult mice. Immunology, 16: 513 (1969).

3. Britton, S., AND Möller, G.: Regulation of antibody synthesis against Escherichia coli endotoxin. I. Suppressive effect of endogenously produced and passively transferred antibodies. J. Immunol., 100: 1326 (1968).

4. Bronson, F. H., DagG, C. P., And Snell, G. D.: Reproduction. In: E. L. Green: Biology of the Laboratory Mouse, ed. 2, p. 187 (McGraw-Hill, New York, 1966).

5. Broome, A. W. J., and Lamming, G. E.: Studies on the relationship between ovarian hormones and uterine infection. III. The role of the antibody system in uterine defense. J. Endocrinol., 18: 229 (1959).

6. Brownlee, K. A.: Statistical Theory and Methodology in Science and Engineering, p. 184, 194 (Wiley, New York, 1965).

7. Butterworth, M., McClellan, B., and Allansmith, M.: Influence of sex on immunoglobulin levels. Nature, 214: 1224 (1967).

8. Cooper, G. N., Halliday, W. J., and Thonard, J. C.: Immunological reactivity associated with antigens in the intestinal tract of rats. J. Pathol. Bacteriol., 93: 223 (1967).

9. Cordingley, J. L.: The mechanism of estrogen stimulation of reticuloendothelial activity. J. Anat., 104: 190 (1969).

10. Dingle, J. H., Meyer, R. K., And Gustus, E. L.: Effect of gonadotropic and oestogenic hormones on the agglutinin response to $B$. pertussis in immature animals. J. Immunol., 30: 139 (1936). 
11. Donovan, B. T., and Van der Werff Ten Bosch, J. J.: Physiology of Puberty, p. 38 (Arnold, London, 1965).

12. Grtuin, D., Rosen, F. S., and Michael, J. G.: Transient 195 gamma-1 globulin deficiency in the newborn infant and its significance. Pediatrics, 31: 197 (1963).

13. Jerne, N. K., ANd Nordin, A. A.: Plaque formation in agar by single antibody-producing cells. Science, 140: 405 (1963).

14. Jerne, N. K., Nordin, A. A., And Henry, C.: The agar plaque technique for recognizing antibody-producing cells. In: B. Amos and H. Koprowski: Cell-bound Antibodies, p. 109 (Wistar Institute Press, Philadelphia, 1963).

15. Kenny, J. F., Medearis, D. N., Kl.ein, S. W., Draghman, R. H., AND GrBson, L. E.: An outbreak of urinary tract infections and septicemia due to Escherichia coli in male infants. J. Pediat., 68: 530 (1966).

16. Kenny, J. F., Woleslagle, D. L., Gray, J. A., Michaels, R. H., ANd Pearson, M. A.: Enteric infection with Escherichia coli 0127 in the mouse. I. Characteristics of infection and systemic and local immune responses in mice of different ages. J. Infect. Dis., 121: 528 (1970).

17. Koros, A. M. C.: A study of the primary immune response, employing the technique of plaque formation in agar by single antibody-producing cells. Ph.D. dissertation, University of Pittsburgh School of Medicine. Diss. Abstr., 26: 3385 (1965).

18. KunIN, C. M.: Antibody distribution against nonenteropathic E. coli. Arch. Intern. Med., 110: 676 (1962).

19. MAYeR, M. M.: Complement and complement fixation. In: E. A. Kabat and M. M. Mayer: Experimental Immunochemistry, ed. 2, p. 133 (Thomas, Springfield, Ill., 1961).

20. MeTCALF, D.: Leukaemogenesis in AKR mice. In: G. E. W. Wolstenholme and M. O'Connor: Tumour Viruses of Murine Origin, p. 233 (Little, Brown, Boston, 1962).

21. MölLER, G.: $19 S$ antibody production against soluble lipopolysaccharide antigens by individual lymphoid cells in vitro. Nature, 207: 1166 (1965).

22. Neter, E., Westphal, O., Lüderitz, O., Gino, R. M., and GoRZYNSKI, E. A.: Demonstration of antibodies against enterpathogenic Escherichia coli in sera of children of various ages. Pediatrics, 16: 801 (1955).

23. Neter, E., Bertram, L. F., Zak, D. A., Murdock, M. R., and ARBESMAN, C. E.: Studies on hemagglutination and hemolysis by Escherichia coli antisera. J. Exp. Med., 96: 1 (1952).

24. Nicol, T., Bilbey, D. L. J., Charles, L. M., Cordinglex, J. L., AND Vernon-RoberTs, B.: Oestogen: The natural stimulant of body defence. J. Endocrinol., 30: 277 (1964).

25. Paul, W. E., Siskind, G. W., and Benacerraf, B.: Specificity of cellular immune responses. Antigen concentration dependence of stimulation of DNA synthesis in vitro by specifically sensitized cells, as an expression of the binding characteristics of cellular antibody. J. Exp. Med., 127: 25 (1968).

26. Preeyasombax, C., and KenNy, F. M.: Urocytograms in normal children and various abnormal conditions. Pediatrics, 38: 436 (1966).
27. Ravin, H. A., Rowley, D., Jenkins, C., and Fine, J.: On the absorption of bacterial endotoxin from the gastro-intestinal tract of the normal and shocksd animal. J. Exp. Med., 112: $783(1960)$.

28. Santistebnn, G. A.: The growth and involution of lymphatic tissue and its interrelationships to aging and to the growth of the adrenal glands and sex organs in CBA mice. Anat. Rec., 136: 117 (1960).

29. Silver, H. K., ANd Kirchner, R. L.: Cytologic study of urinary sediment in the evaluation of sex hormone production in childhood. Pediatrics, 38: 886 (1966).

30. Silverman, W. A., and Homan, W. E.: Sepsis of obscure origin in the newborn. Pediatrics, 3: 157 (1949).

31. Stern, K., AND Davidsohn, I.: Effect of estrogen and cortisone on immune hemoantibodies in mice of inbred strains. J. Immunol., 74: 479 (1955).

32. Terres, G., Morrison, S. L., and Habicht, G. S.: A quantitative difference in the immune response between male and female mice. Proc. Soc. Exp. Biol. Med., 127: 664 (1968).

33. Thompson, J. S., Crawford, M. K., Reilly, R. W., and Severson, C. D.: The effect of estrogenic hormones on immune responses in normal and irradiated mice. J. Immunol., 98: 331 (1967).

34. Torvanen, P.: Effect of estrogens on the humoral antibody response in guinea pigs. Ann. Med. Exp. Biol. Fenn., 45: 152 (1967).

35. Tsao, S. N.: Bactericidal property of blood serum of male rabbits treated with urinary estrogens. Proc. Soc. Exp. Biol. Med., 48: 38 (1941).

36. Von HaAm, E., and Rosenfeld, I.: The effect of estrone on antibody-production. J. Immunol., 43: 109 (1942).

37. Washburn, T. C., Medearis, D. N., and Childs, B.: Sex differences in susceptibility to infection. Pediatrics, 35: 57 (1965).

38. WeInstein, L.: The effect of estrogenic hormone and ovariectomy on the normal antibody content of the serum of mature rabbits. Yale J. Biol. Med., 11: 169 (1939).

39. Wheater, D. W. F., and Hurst, E. W.: The effect of sex on bacterial infections in mice and on the chemotherapy of one of them. J. Pathol. Bacteriol., 82: 117 (1961).

40. Wortis, H. H., Dresser, D. W., and Anderson, H. R.: Antibody production studied by means of the localized hemolysis in gel (LHG) assay. III. Mouse cells producing five different classes of antibody. Immunology, 17: 93 (1969).

41. Progynon, Schering Corporation, Bloomfield, N. J.

42. Presented in part at the annual meeting of the Midwest Society for Pediatric Research, Rochester, Minn., November $5,1969$.

43. Supported by National Institutes of Health Research Grants nos. HDO2866 and FRO5507.

44. The authors thank Dr. Floyd Taylor for portions of the statistical analysis and Dr. David Gitlin for his helpful advice.

45. Requests for reprints should be addressed to: Jean F. Kenny, M.D., Children's Hospital of Pittsburgh, 125 De Soto Street, Pittsburgh, Pa. 15213 (USA).

46. Accepted for publication August 14, 1970. 